\title{
The Prospects for Customary Law in Transitional Justice: The Case of Fiji*
}

\section{Joanna R. Quinn**}

The use of customary law shows real promise in addressing the challenges that arise when confronting the legacies of past human rights abuses and atrocities. Unlike typical transitional justice mechanisms like trials, truth commissions, and reparations programs, customary practices are community-based and well-known to the people who use them. Indeed, customary practices could be used in transitional societies in place of "foreign" practices to bring about the same objectives. This paper considers the role that customary law plays in Fiji. It further assesses the prospects for the use of customary, traditional law in situations where transitional justice is called for.

Le recours au droit coutumier semble prometteur pour relever les défis qui se posent au moment de confronter l'héritage des violations des droits de la personne et des atrocités commises par le passé. Contrairement aux mécanismes typiques de justice transitionnelle comme les procès, les commissions de la vérité et les programmes de réparation, les pratiques coutumières sont axées sur la communauté et bien connues des personnes qui y ont recours. En effet, les pratiques coutumières pourraient être utilisées dans les sociétés transitionnelles au lieu de pratiques "étrangères " pour réaliser les mêmes objectifs. Dans ce présent, nous nous penchons sur le rôle que joue le droit coutumier à Fidji. Nous y évaluons également la possibilité de recourir au droit coutumier traditionnel dans les situations qui se prêtent à la justice transitionnelle.

Transitional justice typically relies on a handful of mechanisms, including trials, truth commissions, and reparations programs, in seeking justice after conflict. ${ }^{1}$ In many societies, however, these mechanisms have less salience and value than customary practices of justice. Customary law, on the contrary, is community-based and well-known to the people who use it. Practices of customary law might reasonably be used in transitional societies, in place of other, "foreign" practices like truth commissions and trials, in bringing about the same objectives sought by the mechanisms more often used.

\footnotetext{
* $\quad$ Research for this project was carried out with assistance from the Social Sciences and Humanities Research Council and with archival research assistance from Tamara Hinan. This paper was first presented at the Annual Meeting of the International Studies Association, Montreal, QB: March 16, 2011

** Director and Graduate Chair, Centre for Transitional Justice and Post-Conflict Reconstruction; Associate Professor, Department of Political Science; Cross-Appointed, Faculty of Law and Affiliate-Appointed, Department of Women's Studies and Feminist Research; President, College of New Scholars, Artists, and Scientists of the Royal Society of Canada, Western University, London, Ontario, Canada

1 My interviewees often spoke interchangeably of traditional, customary, or informal practices. I have chosen to standardize this by use of the term "customary".
} 
Fiji is still in a period that might be considered pre-transitional, and it is perhaps too soon to begin looking for solutions to effect the illusive transition in Fiji. Fiji lived in a state of "suspended animation" 2 from the first of four coups in 1987, and this has only recently begun to change. A new constitution was promulgated in 2013 and elections were held in 2016, though the leader of the 2006 coup, Commodore Bainimarama, remains in power. Still, a number of important questions must be considered: At what point in any given peacebuilding process do we need to intervene? Should scholars and practitioners be looking ahead to assess particular strategies well ahead of time? Or should we wait until some future opportunity to begin to sort out what comes next in such communities? One of my interviewees told me the kinds of questions I was asking were important, but only half-jokingly said that I was a few years too early and should come back once things had settled down. ${ }^{3}$

This paper considers customary law in a context that is neither, strictly speaking, "transitional," nor broadly representative. It seeks to contribute to our understanding of the challenges faced in failed and fragile states when working toward effecting any real transition. These are not "ideal" conditions in which to test the kinds of ideas advanced in this paper. Yet transitional societies rarely represent an ideal type.

\section{METHODOLOGY}

I am particularly interested in processes of coming to terms with the past, and how that facilitates the acknowledgement of past events. ${ }^{4}$ Acknowledgement is a necessary but not sufficient condition in the process of rebuilding. This means publicly admitting to and accepting a knowledge of the events which have taken place so things like social trust and reconciliation can begin to develop. In many communities, past crimes are simply never discussed. Rather, events and their consequences are left to bubble under the surface. Unless these atrocities are both privately and publicly acknowledged by individuals within a society, it cannot move forward on the continuum of social rebuilding.

I conducted a 10-year study of the utility of customary practices of justice and acknowledgement as a potential mechanism of transitional justice to understand the role that these processes can and do play in a society's acknowledgement of past crimes and abuses. And how they are able to succeed where other "Western" approaches, like the truth commission, have failed..$^{5}$ The study was carried out in Uganda, Fiji, and Solomon Islands.

In June and July 2010, I conducted field research in Fiji Islands. My goal was to see whether customary practices of justice are used in Fiji, and where they are, to understand their similarity to the kinds of

2 In medical terminology, suspended animation refers to the slowing of vital functions by external means without resulting in death.

3 Joseph Camillo, Executive Director, Ecumenical Centre for Research, Education and Advocacy (ECREA), interview by author (29 June 2010, Suva, Fiji).

4 Joanna R. Quinn, 2010, The Politics of Acknowledgement (Vancouver: UBC Press).

5 Joanna R. Quinn, "Mad Science? Possibilities for and Examples of Synthetic (Neo)traditional Practices of Justice and Acknowledgement/Science folle? Possibilités et exemples de pratiquest (néo-) traditionelles synthétiques de justice et de confession" (2014) 5:3 Air and Space Power Journal-Africa and Francophonie, 48-66; Joanna R. Quinn, "Tradition?! Traditional cultural institutions on Customary Practices in Uganda" (2014) 49:3 Africa Spectrum, 29-54; Joanna R. Quinn, "The impact of internal conflict on customary institutions and law: the case of Uganda" (2015) 58:1 Journal of African Law, 220-236. 
practices I had seen in Uganda. I sought to answer three questions: first, to determine prevailing attitudes toward the use of customary mechanisms in the social rebuilding process; second, to evaluate the feasibility of utilizing customary mechanisms in the context of international law, national regulations and local custom; and, third, to understand how the use of these kinds of customary mechanisms is affected by differences in conflicts.

I conducted 26 in-depth interviews, and historical and archival research. My interviewees included academics, government officials including the Solicitor General and the Chief Justice of the Supreme Court, opposition politicians, members of the chiefly community, commonly called the House of Chiefs, members of the NGO community, religious leaders, and others. In all cases, I asked about the continued practice of customary justice, and about the legislation of such practices. The answers they provided have shaped this paper.

In some cases, it was politically dangerous for the people to whom I spoke to be named. Although I received permission to identify everyone whom I interviewed, I have chosen not to do so in some cases. In most cases, I have presented the comments those interviewees made as direct quotations, although their names have not been included. With the express permission of the interviewee, I have attributed most direct quotations. Where I did not, the interviewees have been variously identified by use of descriptors meant to explain their particular role in Fijian society, their political affiliation, or an experience they have had.

\section{HISTORY AND BACKGROUND}

Fiji was discovered by Europeans in 1643. By 1800, shipwrecked European sailors had begun to inhabit the islands, soon followed by Christian missionaries. ${ }^{6}$ This caused significant upheaval within the Indigenous Fijian communities. For financial reasons, the paramount chief of Fiji, (King) Cakobau... turned to the British for assistance and eventually and reluctantly ceded his country to the UK in return for the payment of outstanding debts and the protection of Fijian interests. And so, on the 10th of October 1874 , with the signing of a treaty, 'The Deed of Cession', Fiji became a colony of Britain. ${ }^{7}$

European relations with Indigenous Fijians became more complicated with the coming of indentured labourers from India in $1879 .{ }^{8}$ The Indians soon made Fiji their permanent home, but they were kept very separate from the Indigenous Fijian population.

The system of governance put in place by the British sought to govern "without departing in any important particular from [the Indigenous Fijians'] own official customs and traditions." established a series of laws, called the Fiji Regulations, to legislate the lives of Indigenous Fijians, and "to preserve their traditional values, ways of living, and political institutions." 10 "Indigenous Fijians were

6 Brij Lal, Broken Waves: A History of the Fiji Islands in the Twentieth Century (Honolulu: University of Hawaii Press, 1992).

7 John E Davies, "Ethnic Competition and the Forging of the Nation State in Fiji" (2005) 94:378 The Round Table 47 at 50.

8 John D Kelly, "Threats to Difference in Colonial Fiji” (1995) 10:1 Cultural Anthropology 65.

9 "Dispatch from Sir Hercules Robinson, 16 Oct. 1874," as cited in R Knox-Mawer, "Native Courts and Customs in Fiji" (1961) 10:3 ICLQ 642.

10 Lal, supra note 6 at 13; "Dispatch,"supra note 9 at 643. 
governed in large part by an increasingly elaborate and codified system of 'customary law,' with its own courts, judges, and administrators. The immigrant, indentured [Indo-Fijian] laborers were 'protected' by an Agent-General of Immigration and his small staff." 11 The European settlers were governed by a separate set of legislative ordinances. ${ }^{12}$ These three separate systems of law and justice existed concurrently.

Boundaries between the three groups were rigorously maintained."13 "[The colonial administration] worked actively to suppress and outlaw pre-colonial and pre-Christian indigenous cultural and religious practices it found troublesome or offensive."14 The British also instituted a "Great Chiefly Council," known as the Great Council of Chiefs, to advise the Governor on native regulation. ${ }^{15}$ This served to isolate Indigenous Fijians, effectively protecting their traditions to the detriment of their community's development. ${ }^{16}$

Over the course of the next decades, social, political, and legal development in the Fiji Islands was tumultuous, challenging the foundations of colonial organization. ${ }^{17}$ Reports from foreign scholars including Professor O.H.K. Spate ${ }^{18}$ and Sir Alan Burns ${ }^{19}$ were commissioned in the late 1950s regarding changes to be made in how Fiji was governed. By the 1950s, unhappiness and ethnic division ${ }^{20 ~ " c o i n c i d e d ~}$ with moves afoot in Britain to give colonies a greater measure of self-government as a step toward full independence." 21 Subsequent constitutional talks left the Indigenous Fijians and Europeans largely satisfied, but the Fijians of Indian descent ${ }^{22}$ were "bitterly disappointed." 23 Fiji became Independent on 9 October $1970,{ }^{24}$ underscored by deep division.

These differences boiled over in a series of political coups: In the first coup, on 14 May 1987, Lt. Col. Rabuka "took over from the elected government in a bloodless coup and formed a civil interim government

11 Kelly, supra note 8 at 65.

12 See, for example, Colony of Fiji, Ordinance VIII of 1875: An Ordinance to Provide for the Judicial Administration of Certain Districts of the Colony (5 November 1875), which regulated the legal apparatus pertaining to Indigenous Fijians, as distinct from Ordinance VII of 1875: An Ordinance to Provide for the Supreme Court, which delineated the powers of the courts and their composition solely for the use of European settlers [Supreme Court Ordinance]. See also ordinances including Ordinance IX of 1875: An Ordinance to regulate the Storage of Gunpowder, (12 April 1876), which prohibited the handling or ownership of gunpowder by Indigenous Fijians, and gave that right solely to European settlers.

13 Kelly, supra note 8 at 65.

14 Lal, supra note 6 at $14-15$.

15 Ibid at 14.

$16 \quad$ Ibid at 16.

17 Ibid at 60.

18 Colony of Fiji, The Fijian People: Economic Problems and Prospects, Legislative (Council Paper No13 of 1959) by OHK Spate (Suva: Government Press, 1959).

19 Colony of Fiji, Report of the Commission of Enquiry into the Natural Resources and Population Trends of the Colony of Fiji, 1959 (Legislative Council Paper No. 1 of 1960) by Sir Alan Burns, (Suva, Government Press, 1960) [Burns'

Report].

$20 \quad$ Supreme Court Ordinance, supra note 12; and Burns' Report, supra note 19.

21 Lal, supra note 6 at 186.

22 "In Western-educated circles in Fiji, the vocabulary of cultural difference is preferred to vulgar references to race, and "Indo-Fijian" is preferred to "Indian" or even "Fiji Indian." (Kelly, supra note 8 at 79.) I have opted to use "Fijians of Indian descent." Thanks to Ashwin Raj for his clarification of this issue.

23 Lal, supra note 6 at 195.

24 Ibid at 214. 
supported by the Great Council of Chiefs." ${ }^{25}$ In the second coup, only a few months later, on 25 September 1987, Rabuka again intervened, this time with military force. The constitution was revoked, and Fiji was declared a republic and suspended from the Commonwealth. ${ }^{26}$ New Constitutions were declared in 1990 and 1997, and upon an apology to Queen Elizabeth, Fiji was readmitted to the Commonwealth. ${ }^{27}$

A third coup was carried out on 19 May 2000 by George Speight. Speight's supporters promulgated a divisive Reconciliation, Tolerance and Unity Bill to "provide for and regulate the processes of promoting effective reconciliation amongst the people of the Fiji Islands following the political and civil unrest and events of 2000." ${ }^{28}$ It aimed to create a truth commission, ${ }^{29}$ to be called the Promotion of Reconciliation, Tolerance and Unity Council. ${ }^{30}$ Opponents saw the amnesty provisions as unsustainable, and civic unrest ensued.

The largely peaceful fourth coup began on 5 December 2006, when parliament was dissolved on the order of Commodore Bainimarama in opposition to the Reconciliation Bill. 31 "Several key groups did not approve of Bainimarama's coup, including the Methodist Church and the Great Council of Chiefs... Bainimarama dissolved the council and... acted as interim prime minister." 32 A High Court case in October 2008 ruled the coup legal under the constitution. ${ }^{33}$ At the time of writing, a new constitution promulgated in 2013 remains in place. Elections were held in 2016. Bainimarama remains as Prime Minister. Parliament is once again sitting. The Great Council of Chiefs, though, was formally abolished in $2012 .{ }^{34}$

\section{CUSTOMARY LAW}

Traditionally, societies around the world had highly complex, highly developed systems for dealing with conflict and conflict resolution - and for dealing with the social deficits brought about by conflict. In traditional times, these systems carried out several functions, including mediation, arbitration, adjudication, restitution, and punishment - the same retributive elements included in the kinds of systems familiar in "modern" justice. They often also included elements of restoration and reconciliation ${ }^{35}$ which typically functioned in tandem.

25 Dean Starnes \& Nana Luckham, Fiji, $8^{\text {th }}$ ed. (Victoria: Lonely Planet Publications, 2009) at 37.

26 Ibid; Lal, supra note 6 at 291-315.

27 Starnes \& Luckham, supra note 25 at 37-38.

28 Government of Fiji, Promotion of Reconciliation, Tolerance and Unity Bill, 2005 at sec 1.

29 Mosmi Bhim, "The impact of the Promotion of Reconciliation, Tolerance and Unity Bill on the 2006 election," From Election to Coup in Fiji: The 2006 Campaign and its Aftermath, eds. Jon Fraenkel and Stewart Firth (Canberra: ANU EPress, 2007), 124.

30 Honourable Laisenia Qarase, Prime Minister and Minister for Fijian Affairs, Statement at second reading of the Reconciliation, Tolerance and Unity Bill (2 June 2005) [on file with Author].

31 Bill Goodwin, Frommer's Fiji, (Hoboken, NJ: Wiley, 2008) at 31.

32 Starnes \& Luckham, supra note 25 at 39.

33 Ibid.

34 Michael Field, "Fiji's Great Council of Chiefs abolished" (14 March 2012), online: Stuff $<$ http://www.stuff.co.nz/world/south-pacific/6573396/Fijis-Great-Council-of-Chiefs-abolished>.

35 Joanna R. Quinn, 2005, “Tried and True: The Role of Informal Mechanisms in Transitional Justice,” (Paper delivered at the International Society of Political Psychology Annual Meeting, Toronto, 6 July) [unpublished]. 
Often, these practices were shoved aside to make way for modern, Western ideas and practices. ${ }^{36}$ Colonial rulers disparaged such traditional customs, and allowed only "natives" within the colonies to utilize them, setting up separate mechanisms for use by "non-natives," effectively creating a dual system. ${ }^{37}$ In some places they are no longer used regularly. In other places, those institutions remain. Traditional practices continue to be used around the world..$^{38}$

There is a growing literature on the use and/or revitalization of customary practices of justice throughout the world..$^{39}$ This is particularly true of the South Pacific, where scholars of legal anthropology, as well as politicians and government officials, are considering the inclusion of customary law within the "Western" legal system. ${ }^{40}$ "When Pacific Island countries gained independence in the latter part of the 20th century some colonial laws were abolished, others were retained as interim measures pending their replacement by national laws. The place of custom and customary law was reassessed and in some cases strengthened as part of the assertion of independence and national identity." 41 Both Vanuatu and Solomon Islands, for example, have constitutionally enshrined the role of chiefly authority in their structures of governance. ${ }^{42}$ There is also, in both countries, "express provision for customs or customary law to be applied as part of the law of the country by all courts." 43

\section{CUSTOMARY LAW IN FIJI}

In Fiji, these customs and traditions were enshrined in the Fiji Regulations (1876). ${ }^{44}$ Then in 1967, the traditional Fijian court system and various related regulations were abolished. ${ }^{45}$ "[B]y 1970 and the enactment of the new constitution, the traditional courts went out of use. They have not been reinstituted

36 Lord Lugard, The Dual Mandate in British Tropical Africa, 5th ed (London: Thomas Nelson, 1965) at 536-569.

37 Mahmood Mamdani, Citizen and Subject (Kampala: Fountain Publishers, 1996) at 109-110.

38 Joanna R. Quinn, "The impact of internal conflict on customary institutions and law: the case of Uganda" (2015) 58:1 Journal of African Law, 220-236.

39 Norbert Rouland, Legal Anthropology, translated by Philippe G Planel (Stanford: Stanford University Press, 1994); Susanne Schmeidl, "Successful Cooperation or Dangerous Liaison? Integrating traditional and modern justice mechanisms in Southeaster Afghanistan" (Paper delivered at the annual convention of the International Studies Association, New York, NY, 15-18 February 2009) [Unpublished]; William I Zartman, ed, Traditional Cures for Modern Conflicts: African Conflict "Medicine” (Boulder, CO: Lynne Rienner, 2000); Luc Huyse \& Mark Salter, eds, Traditional Justice and Reconciliation after Violent Conflict: Learning from African Experiences (Stockholm: International Institute for Democracy and Electoral Assistance, 2008).

40 Stephanie Lawson, Tradition vs. Democracy in the South Pacific: Fiji, Tonga and Western Samoa (Cambridge: Cambridge University Press, 1996); Guy Powles, "Law, Courts and Legal Services in Pacific Societies," in Guy Powles \& Mere Pulea, eds, Pacific Courts and Legal Systems (Suva, Fiji: University of the South Pacific, 1998); Anita Jowitt \& Tess Newton Cain, eds, Passage of Change: Law, Society and Governance in the Pacific (Canberra: Pandanus Books, 2003); Miranda Forsyth, "A Typology of Relationships between State and Non-State Justice Systems” (2007) 56 J Leg Pluralism \& Unofficial L 67.

41 Sue Farran, "Palm Tree Justice? The Role of Comparative Law in the South Pacific" (2009) 58 ICLQ 182.

42 See Powles, supra note 40.

43 Jennifer Corrin Care, Tess Newton \& Don Paterson, Introduction to South Pacific Law (London: Cavendish Printing, 1999).

44 Mere Momoivalu, “A Separate System of Justice” The Review (September 1994) 40.

45 Ratu Filimone Ralogaivau, “A Primer on Fiji's Great Council of Chiefs” Fiji Times (27 April 2006). 
and Magistrates now visit the more distant villages on circuit to adjudicate on criminal and civil matters."46 "There is a join between the traditional system and the Western system, but not for serious cases like murder, rape, robbery with violence, and that kind of thing. There, we simply must apply [Western] legal principles, which are important in the community." 47 Yet these practices were legally protected and even encouraged to a large extent until 1997.

Colloquially, there is strong evidence that these practices have continued to exist beyond their official abolition. "There is officially no such thing as customary law in Fiji, but it's really a matter of definition. Most of our customs have been codified, and it is sometimes difficult to distinguish, now, what is customary law."48

Different customary practices traditionally existed to resolve conflict and to reconcile the population. These are called, collectively, $i$ soro. ${ }^{49}$ For example, the matanigasau is a ceremony which aims to restore peace and harmony to the heart of the extended family group, when one party goes to ask forgiveness. Other ceremonies of pardon also exist, such as the bulu, in cases of injury, ${ }^{50}$ to "bury the bad thing that has happened." ${ }^{51}$ Another, veisorosorovi, "brings both parties together to sit, discuss, and agree together, after which a tabua [whale's tooth] is always presented to seal what has been agreed upon. Once the tabua is presented, that's the end of it. Sometimes the tabua can be a curse, because you must follow what you've agreed to by accepting it." 52 All of these are bound up with customary forgiveness and reconciliation, and may be used instead of the Western court system or in conjunction with it. "53 "Even until today, if there are some problems, people will use the village system, a committee set up to resolve their problems. In rural areas, everybody talks together in a traditional way, on mats, under a tree, and so on." 54

Within the community of Fijians of Indian descent, similar customary practices of law existed, and were used to govern-here, too, borne out of necessity, as the European laws extended only to the European community, and the Fijian Regulations extended only to the Indigenous Fijian community. They were called panchayats, and were based on the panchayats in rural India, where "the jurisdiction of the panchayat is wide: everything having to do with the caste or its members... They handle[d] cases as serious as death by poisoning or causing severe injury, but most cases [were] less dramatic: arguments about marriage arrangements, insults, fighting with weapons, or infringement of someone's hereditary territory

46 Christopher T Pryde, Solicitor General of Fiji, correspondence with author (8 February 2011).

47 Honourable Justice Anthony Gates, Chief Justice of Fiji, interview by author (29 June 2010, Suva, Fiji).

48 Alipate Qetaki, General Manager, Fiji Land Trust Board, interview by author (2 June 2010, Suva, Fiji).

49 M Toro, "Disputes in a Fijian Village Setting," (MA Thesis, University of the South Pacific, 1973) [unpublished]; Andrew Arno, "Ritual of Reconciliation and Village Conflict Management in Fiji" (1976) 47:1 Oceania 49.

50 Viviane Cretton, “Cakobau's Sisters: Status, Gender and Politics in Fiji” (2004), Gender Relations Centre, RSPAS, The Australian National University/University of Lausanne, Switzerland Working Paper No. 11 at 2.

51 Salabogi, interview by author (23 June 2010, Suva, Fiji).

52 Ibid.

53 Ibid; Steven Ratuva, "Re-inventing the cultural wheel: re-conceptualizing restorative justice and peace building in ethnically divided Fiji," in A Kind of Mending: Restorative Justice in the Pacific Islands, ed. Sinclair Dinnen with Anita Jowitt and Tess Newton Cain (Canberra: Pandanus Books, 2003)149 at 155-160.

54 Naomi Matanitobua Raiki, former Chief Magistrate, interview by author (28 June 2010, Nausori, Fiji). 
predominate." 55 Fijian panchayats were ad hoc councils ${ }^{56}$ of "men of generally acknowledged reputation... with the power to demand any penalty [they thought] fit (an apology, a fine) or to dismiss the case. But council leaders [had] no power to enforce their decision. This is left to the weight of public opinion." 57 "All the panchayats recorded were ad hoc bodies, called to hear a specific dispute, rather than permanent entities organized on a territorial or cultural basis." 58 They heard evidence presented by both sides, conferred, and handed down their decisions. ${ }^{59}$ These practices no longer exist.

The task faced by the panchayat is one of finding facts, in the sense of creating a definitive public account of what happened in the incident in question. This point needs stressing: the panchayat is held precisely because there is as yet no commonly accepted knowledge of an important event. While many members of the community may already have some knowledge of the incident, such knowledge is unauthorized and cannot be used in public discourse... The purpose of the panchayat is to create what Brenneis calls a "public record" of the dispute: "a single and non-contradictory account of crucial events" which can be used to guide future behaviour... The outcome of a successful panchayat is that the disputants shake hands and resume some semblance of normal social relations. ${ }^{60}$

Even after Independence in 1970, all of these practices, both within the Indigenous Fijian community and within the community of Fijians of Indian descent, continued to be legally sanctioned. ${ }^{61}$ As far back as 1984, the Great Council of Chiefs advocated for reinvigorating the Fijian court system. In 1994, backed by the chiefs, the Ministry of Fijian affairs came out strongly in favour of using the customary court system during a Commission of Inquiry on the Courts. ${ }^{62}$ Between 1990 and 2005, for example, the Government of Fiji

provided grants totalling $\$ 3,364,488$ as at 31/12/04 to the Fijian Affairs Board through the Ministry for the purpose of establishing a Fijian Court System... Although the Fijian Court System [was never] established, grants to Fijian Courts continued to be disbursed [and were instead] utilized in administering a Fijian Court Unit, which... [provided] legal services for domestic cases such as divorces and adoptions. ${ }^{63}$

Some of this money was funneled to a pilot project wherein six traditional leaders were initially appointed as Grade III Magistrates - although eventually at least one was appointed first to Grade II, and then to

55 Robert M Hayden, "Turn-Taking, Overlap, and the Task at Hand: Ordering Speaking Turns in Legal Settings" (1987) 14:2 American Ethnologist 256.

56 Adrian C Mayer, “Associations in Fiji Indian Rural Society” (1956) 58:1 American Anthropologist 104 [Mayer, "Associations"].

57 Adrian C Mayer, "Factions in Indian and Overseas Indian Societies, Part 4: Factions in Fiji Indian Rural Settlements" (1957) 8:4 British J Sociology 319.

58 Mayer, "Associations" supra note 56 at 104.

59 Ibid.

60 Hayden, supra note 55 at 261.

61 Isireli T Fa, Customary Land Rights over Native Land in Fiji: An analysis of the legal status of customary land rights in the Fijian courts (LLM Thesis, University of Auckland, Faculty of Law, 1989) [unpublished].

62 Momoivalu, supra note 44 at 40-43.

63 Government of Fiji, Auditor General, Report of the Auditor General of the Republic of Fiji Islands to Parliament-August 2005 (Suva: Ministry of Fijian Affairs, Culture and Heritage, August 2005) at sec.12. 
Grade I Magistrate - to hear cases using a customary approach. ${ }^{64}$ Then-Chief Magistrate Naomi Matanitobua established the system, known as "Problem-Solving Courts." Their purpose was to try to address the high numbers of Indigenous Fijians then in prison, to try to affect reconciliation by using "all our skills-legal training and customary justice. All courts and magistrates do this in rural areas. We didn't see it as racist. We simply targeted those 25 years and younger, including other races, and looked into their traditional systems too. When we were looking at cases of Fiji Indians, the magistrates would sit in court with help from the elders from their community." 65

Current programs within the prison system have also been making use of the customary structure. "Sevusevu is used as a sacred way of beginning a conversation, a grounding on which everything else must proceed." "Framing issues in traditional ways is useful in getting people to buy in. The NGO Coalition and Dialogue Fiji use this kind of approach." ${ }^{67}$ Even proper judges of the Courts in Fiji use the customary setting to gain buy-in. "I would come into a courtroom to find a chair and table provided and everyone sitting on the floor. And so I would push the table aside and sit on the floor myself, consulting the elders as I went along." 68 A similar understanding was echoed even by the Chief Justice of the Supreme Court. $^{69}$

Today, however, customary law is no longer formally recognized as a general source of law by the constitution. ${ }^{70}$ The Constitution Amendment Act 1997 omitted Section 100.3 of the 1990 Constitution which stated: "Until such time as an Act of Parliament otherwise provides, Fijian customary law shall have effect as part of the laws of Fiji." Yet Section 195.2.e of the subsequent 1998 Constitution did protect customary law to some extent. It said, "All written laws in force in the State (other than the laws referred to in subsection (1)) continue in force as if enacted or made under or pursuant to this Constitution and all other law in the State continues in operation." Likewise, Section 186.1 was explicit in upholding laws related to customary law: "Parliament must make provision for the application of customary laws and for dispute resolution in accordance with traditional Fijian processes." "71 The abrogation of the Constitution in 2009 put an end to the recognition of customary law as a general source of law in Fiji. These have never been reestablished.

Yet the Western justice system in Fiji itself turns to customary practices from time to time. "Customary law and penal law do not flow seamlessly. For example, the courts can't handle traditional matters."72 This is an indication of the truly important role that customary law plays in Indigenous Fijian society. One particularly interesting case involved the inheriting of the title of Tui Cakau, the Paramount Chief of

64 Aminiyasi Katonivualiku, former Traditional Magistrate, interview by author, (25 June 2010, Suva, Fiji).

65 Raiki Interview, supra note 54.

66 Tui Clary, doctoral candidate, Otago University, interview by author (24 June 2010, Suva, Fiji).

67 Camillo Interview, supra note 3.

68 Salote Kaimacuata, former judge, interview by author (25 June 2010, Suva, Fiji).

69 Gates, supra note 47.

70 Professor Jennifer Corrin confirmed that "neither the 2013 Constitution nor legislation recognizes customary law as a general source of law in Fiji, except in relation to title to customary land." Email from Jennifer Corrin to author (25 Sep. 2016); see also Jennifer Corrin Care, "The Status of Customary Law in Fiji Islands after the Constitutional Amendment Act 1997” (2000) 4:1 J South Pac L 1.

71 Ibid at 1.

72 Unnamed opposition supporter, interview by author (23 June 2010, Suva, Fiji). 
Cakaudrove Province. ${ }^{73}$ The title is seen as the third most influential customary title in Fiji, and was contested in $2005 .{ }^{74}$ For the purposes of this discussion, it is important that the case was first heard in a series of customary and traditionally-constituted courts: in the village courts, then in the Tikina (provincial) courts, then by the Native Land Trust Board, a constitutionally-appointed arbitration board that hears customary disputes, largely on questions of land ownership. Only then was the case of the Tui Cakau heard in the High Court. When it was found that "the other body failed to accord due process or fairness, ${ }^{75}$ the case was then heard by the Supreme Court, the final appellate court-which determined that it did not have jurisdiction over customary questions such as titlementship. ${ }^{76}$ Ultimately, the Supreme Court referred the case to the Native Land Commission Court, the court of highest customary legitimacy. Many of my Fijian interviewees referred to the case of the Tui Cakau when explaining to me the fluidity for Indigenous Fijians between customary and Western law.

\section{PROBLEMS}

Within the Indigenous Fijian community, there was some support for bringing back the comprehensive use of customary law. Throughout 2010, the reinstatement of customary law in rural villages through the "Village Bylaws" was being furiously debated, although Bainimarama afterward ruled that such rules are not enforceable and are meant purely as guidelines for social behaviour. ${ }^{77}$ "There has been a lot of talk about reviving the Fijian Courts, as part of the central magistracy. Because of changing demographics, the Fijian Affairs Board has tried to address these changes through the Village Bylaws, which will regulate life in the village, bring about respect for the elders, and respect for our traditions. When in town, people will be subject to municipal laws, but they will be bound by the village laws when in the village." $78 \mathrm{~A}$ representative of the Fiji Human Rights Commission explained to me that "These are simply a remake of the Fijian Affairs Regulations that died out in the 1980s and some are trying to revive them." 79 The Chief Justice told me at that time, "The government is not keen on bringing the courts back."

One common sentiment expressed was that "people are trying to return to their traditions. Maybe that's an overstatement, but there's an urge to get back to the basics. At issue now are not racial issues, but bread-and-butter issues like bus fare, school fees, and that kind of thing." ${ }^{.11}$ Bainimarama, however, has also said that "all villages should see that the chiefly hierarchy is observed and transparency should prevail

73 Alumita Durutalo, "Defending the Inheritance," in Understanding Oceania, eds. Stewart Firth and Vijay Naidu (Canberra: ANU Press, 2019), 179-192.

74 John Fraenkel, "Power Sharing in Fiji and New Caledonia" in Stewart Firth, ed, Globalization and governance in the Pacific Islands (Australia National University, 2006) 341.

75 Gates, supra note 47.

76 Sovanatabua Colavanua, B.S. Legal Officer (Litigation), Fiji Human Rights Commission, interview by author (16 June 2010, Suva, Fiji).

77 Salina Navuso, "Village by-laws not to be enforced by villages" (November 2010) Fijian Custom and Culture 9, online $<$ www.fijiancustomculture.blogspot.com/2010/11/village-by-laws-not-to-be-enforced-by-html>.

78 Ratu Meli Bainimarama, Minister of Fijian Affairs, Culture and Heritage, interview by author (23 June 2010, Suva, Fiji).

79 Colavanua, supra note 76.

80 Gates, supra note 47.

81 Qetaki, supra note 48. 
amongst the villages and the chiefs, by way of regular meeting and negotiations"- upholding the chiefly structure and, with it, the use of custom. ${ }^{82}$

But "most Fijians who live in urban areas have completely lost touch with their culture. Now more than $50 \%$ of the Fijian population is living in the city. Those who were born in cities from 1970 onward are now almost 40 years of age, and they have lost their culture." ${ }^{13}$ This sentiment was voiced as early as 1994, when critics of the customary courts claimed that its supporters "want[ed] to administer archaic punishment to a society that has changed." ${ }^{4}$ Indeed, today "Fijians are spread out throughout the Fiji Islands" and do not live in traditional village structures. ${ }^{85}$ Some now question the relevance of customary institutions in rapidly urbanizing, modernizing, and globalizing societies. ${ }^{86}$ "When people leave their village, they leave some of their culture behind." 87 They worry that, "the traditional values, cultural knowledge and social institutions of everyday life are threatened." 88 And as people move farther away from their gemeinschaft communities, the social meanings of the ceremonies that are still practiced appear to be shifting. ${ }^{89}$ In modern gesellschaft societies, the resulting society is not homogenous but heterogeneous. So carrying out cultural practices becomes more difficult. Homogeneity seems a likely factor in whether or not, and whose, "traditions" are used in a given community. ${ }^{90}$

Still I was told that "people do keep close ties [to their village]. For example, an adult male would be expected to contribute to government fund-raising, such as for village meeting halls, scholarship funds, and that kind of thing. There would be repercussions if he didn't participate, and he would lose the support of his fellow villagers." "P1 "People living in the urban areas have not completely lost touch with their tradition and culture. We have asked the Ministry of Education to reinforce cultural education. We are now carrying out a cultural mapping program, and will revive it." 92

There is a divide across age-groups, too, as to the support demonstrated for customary law. "Parents know about custom, but it's a memory. The young people don't know." 93 "Custom and tradition is not understood as deeply by the young people. But the elders find comfort in understanding custom's regimentedness and orderliness." 94 There is growing concern in the villages about the behaviour of young people, for example, how women should dress. Some have never experienced life in the village, and so they don't know. We have always tried to ask people to go back to their village, at least for a visit. There is still a lot of movement back to the villages. ${ }^{95}$

82 Navuso, supra note 77.

83 Bainimarama Interview, supra note 78.

84 Momoivalu, supra note 44 at 40.

85 Secretariat of the Pacific Community, Fiji Islands Population Profile Based on the 1996 Census (New Caledonia: Secretariat of the Pacific Community, 1999) at 15.

86 Quinn, "The impact of internal conflict on customary institutions and law."

87 Paul Geraghty, Professor, University of the South Pacific, interview by author (2 June 2010, Suva, Fiji).

88 Sverker Finnström, Living With Bad Surroundings: War and Existential Uncertainty in Acholiland in Northern Uganda (Uppsala: Acta Universitatis Upsaliensis, Uppsala Studies in Cultural Anthropology, 2006) at 201.

89 Ibid at 298.

90 Quinn, "The impact of internal conflict on customary institutions and law."

91 Geraghty Interview supra note 87.

92 Bainimarama Interview, supra note 44.

93 Qetaki Interview, supra note.

94 Geraghty Interview supra note 87.

95 Bainimarama Interview, supra note 44. 
The role of Christianity has served to confound the issue-although "it is never really openly discussed."96 "The Roman Catholic church has a policy of inculturation," Catholic Archbishop Petero Mataca explained to me. "But the first missionaries had no idea about inculturation. To them, all things indigenous were of the devil. And the Methodists still reject tradition." ${ }^{97}$ He cited instances of interfaith services organized through the Fiji Council of Churches, where Methodist and Salvation Army pastors refused to take part because of the presence of customary practices. ${ }^{98}$ "It's complicated by the evangelicals, especially the New Methodists, who don't allow yaqona [traditional brew used in customary ceremonies]. They have a lack of tolerance for culture. It's splitting the villages. The first missionaries were very good at using existing symbols and not rejecting tradition. But not the charismatic evangelicals. These days, faith definitely polarizes." 99

One of the biggest problems facing Fiji is that of reconciling "competing, indeed, incompatible interests - paramountcy for Fijians, parity for Indians, and privilege for Europeans - [which] is a central theme of the history of Fiji in the twentieth century. ${ }^{100}$ Yet within the Indigenous Fijian community, the people with whom I spoke indicated near-unanimous support for customary law, at least to some extent.

Customary practices are imbued with an overwhelming amount of cultural significancewithin the Indigenous Fijian community. For example, after the third coup, in which Speight and his men had held the Prime Minister and several Members of Parliament hostage for nearly two months, it was seen to be important to have a matanigasau:

At the end of the hostage crisis, Adi Litia Cakobau called for a meeting of all the chiefs of Fiji, the Bose ni Turaga. Adi Litia Cakobau was the deputy chairperson for the Great Council of Chiefs (GCC) at that time. At the end of the hostage crisis, the chiefs met in Suva on the 12th of July. A special guest chaired the Bose ni Turaga: Adi Samanunu Cakobau, who is Adi Litia's eldest sister. Being High Commissioner for Fiji in Malaysia, Adi Samanunu came especially from Kuala Lumpur to attend the meeting. At the end of the meeting people from Naitasiri-a province involved with supporting the coup and which also traditionally engaged in warfare for the Cakobau-presented her with a ceremony of apology, a matanigasau, on behalf of all the people behind George Speight, the visible leader of the coup. Offering her a tabua - that is, the tooth of a whale-they asked all the chiefs in Fiji to forgive the violence, troubles and the civil conflict engendered by the coup. The following day the remaining hostages were released. ${ }^{101}$

Outside of the Indigenous Fijian community, however, Europeans and Fijians of Indian descent also have at least a healthy respect for the Indigenous Fijian customary practices. Although not as easy to find in colloquial parlance, there are examples of inter-cultural reconciliation rites being performed as well. For

\footnotetext{
96 Camillo Interview, supra note 3.

97 Petero Mataca, Archbishop, Roman Catholic Church of Fiji, interview by author (17 June 2010).

98 Ibid.

99 Clary Interview, supra note 66.

100 Lal, supra note 6 at 16.

101 Cretton, “Cakobau's Sisters," supra note 50 at 1.
} 
example, one such traditional ceremony of acknowledgement was reportedly held at the time of the Speight coup:

Speight did not release the hostages before conducting a final ritual, what ethnic Fijians call a soro, a ritual of apology. Isireli Vuibau, a Labour Party member [sic] of Parliament and fellow hostage, acted as matanivanua, 'herald' or 'talking chief' for deposed Prime Minister Chaudhry. Vuibau accepted the apology. The first bowl of yaqona was passed to Chaudhry and Chaudhry drank it, a culminating moment in a soro. ${ }^{102}$

It is as important to note, here, that Prime Minister Chaudhry, an outsider to the Indigenous Fijian community, and himself a Fijian of Indian descent, participated in the ceremony, as it is to note that the ceremony itself took place. ${ }^{103}$

\section{CONCLUSIONS}

Indigenous Fijian customary practice is commonly carried out in Fiji, despite lacking legal status. "These practices, far from being dislocated in a past that no longer exists, have always continued to be situated socially. They are called upon to address present concerns. Of course, like any culturally informed practice, with time they shift in meaning and appearance." 104 Yet their meanings are still clear, and it is obvious that many - including Commodore Bainimarama - accord them great significance.

These customary practices might well be used to put together a comprehensive set of mechanisms that could one day be harnessed in rebuilding the social fabric of Fijian society. Indigenous Fijians strongly believe in and frequently utilize customary law and traditional practice. That there is already robust buyin of the principles they embody, and compelling evidence to support their understanding, makes their use in post-conflict circumstances seem vital. "Mobilising aspects of local culture as a means of addressing conflict is an important dimension of... justice." 105

The presence of nearly half of the population of Fiji that does not come from a traditional understanding of these mechanisms complicates such a plan. Yet there is also strong evidence to support interest in and acceptance of customary Indigenous Fijian practices within the community of Fijians of Indian descent, and among Europeans - as far-reaching as the Chief Justice of the Supreme Court. Fijians of Indian descent claim that their own historical use of the panchayat has in some ways primed them to understand implicitly what is at play.

102 John Dunham \& Martha Kaplan, Represented Communities: Fiji and World Decolonization (Chicago: University of Chicago Press, 2001) at 143-144.

103 Cretton proposes that the drinking of yanqona was "neither part of a matanigasau, nor an $i$ soro... no tabua presentation having been made" and that some "have made use of traditional ceremonies for political ends." Viviane Cretton, "Traditional Fijian Apology as a Political Strategy"(2005) 75 Oceania 403 at 405.

104 Finnström, supra note 88 at 299.

105 Ratuva, "Re-inventing the cultural wheel" supra note 53 at 161. 
Putting in place an "acceptable cross-cultural synthesis of [the Indigenous Fijian] reconciliation model" seems a likely way to proceed. ${ }^{106}$ Ratuva claims that "these same principles can be re-designed and used as a basis for conflict resolution at the national level." ${ }^{107} \mathrm{He}$ argues that the customary Indigenous Fijian model has a number of strengths, including its maleability, depending on the circumstances in which it is constituted; its customary use in communal conflict resolution; and its utility in transforming relationships. ${ }^{108}$

The prospects for customary law in transitional justice, at least in the Fijian case, are promising. What remains to materialize is an appropriate opportunity, a proper "transition" or opening, for a customary experiment to be tried.

106 Frank Hoare, "Building Inclusive Community in a Divided Society: From separate ethnic inculturation to an intercultural dialogue of faith in the multi-ethnic context of the Catholic Church in Fiji" (DMin. Dissertation, Catholic Union at Chicago, 2008) [unpublished ; see also Frank Hoare, "Community Trauma Healing in Fiji" (undated manuscript) [unpublished], on file with author at 17-18.

107 Ratuva, "Re-inventing the cultural wheel," supra note 53 at 160.

108 Ibid at $160-161$. 